\title{
HUBUNGAN DUKUNGAN KELUARGA DENGAN KONSEP DIRI PASIEN STROKE DI RUMAH SAKIT SANTA ELISABETH MEDAN
}

\author{
Pomarida Simbolon \\ STIKes Santa Elisabeth Medan \\ Email:pomasps@yahoo.com
}

\begin{abstract}
Stroke is a symptom that occurs due to impaired blood circulation in the brain. Stroke diseases has the third death sequence in the world after heart disease and cancer. Good family support is needed in improving self-concept for stroke patients. This research which aims to determine the relationship of family support with self-concept in patients with stroke in Santa Elisabeth Hospital Medan. The design used in research was analytic survey design using the "cross-sectional" with a sample of 34 respondents and the sampling technique is purposive sampling. The data were collected by questionnaires and held in April 2016. Data analysis using chi-square test with significance level of 5\%. Results of the study revealed that good family support $(55,9 \%)$ and negative self-concept $(65,6 \%)$. The result of statistical test family support with self-concept value $p=0,004(p<0,05)$ It means there was significant relationship the family support with self-concept in stroke patients in Santa Elisabeth Hospital Medan. It was expected to nurses improve service to patients, motivate and assistsick family members and nurses work with the famiies in maintaining self concept patients. As for the family was expected to pay attention to patients health condition, motivate sick family members by giving motivation to recover, and assisting the patient in the process of healing.
\end{abstract}

Keywords: Family Support, Self -Concept, Disease Stroke

\begin{abstract}
ABSTRAK
Stroke merupakan gejala yang terjadi akibat gangguan sirkulasi darah di otak. Penyakit stroke memiliki urutan kematian ketiga di dunia setelah penyakit jantung dan kanker. Dukungan keluarga yang baik sangat diperlukan dalam meningkatkan konsep diri bagi penderita stroke. Penelitian ini bertujuan untuk mengetahui hubungan dukungan keluarga dengan konsep diri pada pasien stroke di Rumah Sakit Santa Elisabeth Medan. Rancangan yang digunakan dalam penelitian ini adalah rancangan survei analitik menggunakan pendekatan "cross sectional" dengan jumlah sampel 34 responden dan teknik pengambilan sampel secara purposive sampling. Metode pengumpulan data dengan menggunakan kuesioner. Penelitian dilaksanakan pada bulan April 2016. Analisis data menggunakan uji chi square dengan tingkat kemaknaan 5\%. Hasil dari penelitian diperoleh bahwa dukungan keluarga yang baik (55,9\%) dan konsep diri yang negatif (67,6\%). Hasil uji statistik dukungan keluarga dengan konsep diri dengan nilai $p=0,004(p<0,05)$ artinya ada hubungan bermakna dukungan keluarga dengan konsep diri pasien stroke. Diharapkan perawat meningkatkan pelayanan kepada pasien, memotivasi dan mendampingi anggota keluarga yang sakit serta perawat bekerjasama dengan keluarga dalam mempertahankan konsep diri pasien. Bagi Keluarga diharapkan memperhatikan kondisi kesehatan pasien, memotivasi anggota keluarga yang sakit dengan memberi motivasi untuk sembuh, serta mendampingi pasien dalam proses penyembuhan
\end{abstract}

Kata Kunci: Dukungan Keluarga, Konsep Diri, Penyakit Stroke 


\section{PENDAHULUAN}

Keluarga merupakan salah satu unit dasar yang bertanggung jawab dalam melestarikan integritas individu anggota keluarga yang akan membentuk struktur keluarga. Keluarga sangat berperan terutama jika ada masalah kesehatan dengan memberikan bantuan dalam bentuk dukungan. Dukungan dari keluarga menjadikan keluarga mampu berfungsi dengan berbagai kepandaian dan akal, sehingga akan meningkatkan kesehatan dan adaptasi mereka dalam kehidupan (Susanto, 2012).

Dukungan keluarga adalah suatu bentuk hubungan interpersonal yang melindungi seseorang dari efek stress yang buruk Dukungan keluarga adalah sikap, tindakan penerimaan keluarga terhadap anggota keluarganya, berupa dukungan informasional, dukungan penilaian, dukungan instrumental dan dukungan emosional. Jadi dukungan keluarga adalah suatu bentuk hubungan interpersonal yang meliputi sikap, tindakan dan penerimaan terhadap anggota keluarga, sehingga anggota keluarga merasa ada yang memperhatikan (Setiadi, 2008).

Dukungan yang diberikan oleh keluarga dapat terwujud melalui pemberian dukungan pada penderita stroke. Secara psikologis, apabila dukungan dari keluarga penderita stroke mampu mengoptimalkan aspek emosional, penghargaan, informasi, dan instrumental berupa perhatian, nasehat, saran, pemberian pekerjaan dan sebagainya maka dukungan keluarga tersebut akan mampu meningkatkan strategi koping pada penderita stroke sehingga penderita merasa bahwa dirinya dibutuhkan, diperhatikan dan merasa bahwa dirinya tidak berbeda dengan manusia yang lain (Hasan, 2013).

Hasil penelitian Lenahatu (2015) di Poliklinik Saraf Rumah Sakit Umum Daerah Dr M Haulussy menyatakan bahwa dukungan keluarga yang baik sebanyak 61 orang $(68,5 \%)$ dan kurang sebanyak 28 orang $(31,5 \%)$, hal ini dapat dilihat bahwa pentingnya dukungan dalam keluarga bagi penderita stroke.

Berdasarkan prevalensi di dunia, menurut WHO (2004) bahwa satu dari 10 kematian disebabkan oleh stroke yang memiliki urutan ketiga di negara-negara maju setelah penyakit jantung dan kanker. Di Amerika Serikat juga stroke penyebab utama kematian ketiga dan membunuh 160.000 orang Amerika setiap tahun. Insiden stroke baru atau berulang setiap tahun sekitar 750.000 dan lebih dari empat juta hidup dengan efek residual stroke yang mencakup kelumpuhan dan cacat. Menurut WHO, 15 juta orang di seluruh dunia menderita stroke setiap tahun. Dari jumlah tersebut, hampir 5 juta meninggal 
dan 5 juta yang tersisa kelumpuhan secara permanen (Mandal, 2014).

Prevalensi stroke di Indonesia meningkat dari 8,3 per mil (2007) menjadi 12,1 per mil (2013). Prevalensi stroke berdasarkan diagnosis tenaga kesehatan tingkat provinsi tertinggi di Sulawesi Utara 10,8 per mil, diikuti DI Yogyakarta 10,3 per mil, Bangka Belitung dan DKI Jakarta masingmasing 9,7 per mil. Prevalensi stroke berdasarkan 92 terdiagnosis tenaga kesehatan dan gejala tertinggi terdapat di Sulawesi Selatan 17,9 per mil, DI Yogjakarta 16,9 per mil, Sulawesi Tengah 16,6 per mil, diikuti Jawa Timur sebesar 16 per mil (Riskesdas, 2013).

Data penelitian pengobatan stroke hingga kini belum memuaskan walaupun telah banyak yang dicapai, hasil akhir pengobatan kalau tidak meninggal hampir selalu meninggalkan kecacatan. Agaknya pengobatan awal/ dini serta pencegahan sangat bermanfaat akan tetapi harus disertai dengan pengenalan dan pemahaman stroke pada semua lapisan dan komunitas dalam masyarakat. (Anderson, 2008).

Dukungan keluarga sangat diperlukan dalam mengubah konsep diri. Klien yang harus beradaptasi terhadap perubahan konsep diri yang disebabkan oleh penyakit stroke.Adapun pengalaman dalam perawatan di rumah sakit dengan penyakit stroke yang dapat mempengaruhi konsep diri dimana terjadinya perubahan citra tubuh seperti kelumpuhan anggota tubuh, bicara pelo, mulut mencong, dan sebagainya. Penyakit stroke mencakup perubahan fungsi, dimana tubuh tidak lagi berfungsi secara optimal sehingga terjadinya perubahan fisik yang dapat mengubah konsep diri seseorang (Potter \& Perry, 2009).

Penderita dengan penyakit stroke dapat menimbulkan respon salah satunya kehilangan konsep diri dimana merasa dirinya berubah mencakup bentuk dan fungsi tubuh sehingga klien tidak dapat berfikir secara rasional peran dan identitasnya. Pada dinamika individu dengan penyakit stroke dapat mengekspresikan rasa tidak percaya diri sesuai kenyataan seperti dengan kalimat "mengapa kejadian ini menimpa saya?", pada kalimat tersebut terjadi proses perubahan konsep diri (Purwaningsih, 2010).

Konsep diri merupakan cara individu memandang dirinya secara utuh, seperti fisik, emosi, intelektual, sosial, dan spiritual. Konsep diri yang positif/kebaikan ditandai dengan kemampuan intelektual dan penguasaan lingkungan. Sementara pada konsep diri yang negatif/ keburukan ditandai dengan hubungan individu dan 
hubungan sosial yang maladaptif atau respon yang buruk (Sunaryo, 2014).

Konsep diri yang positif diperoleh melalui proses interaksi dan pengalamanpengalaman yang diterima, yang merupakan hasil eksplorasi terhadap lingkungannya serta refleksi diri yang diterima dari orang lain yang berarti dalam kehidupannya (Saam \& Wahyuni, 2012). Kepribadian sehat akan terdapat citra tubuh yang positif/sesuai, ideal diri yang realistis, konsep diri positif, harga diri yang tinggi, penampilan peran yang memuaskan dan identitas yang jelas. Maka, terdapat respon konsep diri sepanjang rentang sehat-sakit berkisar dari status aktualisasi diri (paling adaptif) sampai pada kerancuan identitas/ depersonalisasi (maladaptif) yang artinya suatu perasaan yang tidak realistis dan keasingan dirinya dari lingkungan (Azizah, 2011).

Rohadirja, dkk (2012) di Poliklinik Saraf RSU Sumedang menyatakan bahwa pada konsep diri pada pasien stroke ringan di dapatkan gambaran diri $20 \%$ memiliki pandangan pribadi yang negatif, ideal diri $70 \%$ masih memiliki harapan dan cita-cita, harga diri 56,67\%, dan memiliki peran yang negatif $26,67 \%$. Dalam aspek konsep diri 46,67\% menyatakan bahwa pasien memandang perubahan dalam dirinya secara negatif, salah satunya pasien merasa tidak disukai orang lain dan tidak dapat menerima keadaannya hal ini akan mempengaruhi konsep diri (Septinopalinda, 2013).

Hasil survei pendahuluan di Rumah Sakit Santa Elisabeth Medan tahun 2015 bahwa terdapat 50 orang terkena stroke. Hasil penelitian Ambarita (2014) di Rumah Sakit Santa Elisabeth Medan menyatakan bahwa terdapat 60 orang responden yang menunjukkan dukungan keluarga baik 34 orang $(58,7 \%)$, dukungan keluarga cukup 8 orang $(13,3 \%)$ dan dukungan keluarga kurang 18 orang $(30 \%)$. Hasil tersebut menunjukkan masih berfungsinya keluarga dalam memberikan dukungan kepada pasien stroke.

\section{METODE}

Penelitian ini menggunakan penelitian survei analitik. Rancangan yang dilakukan menggunakan pendekatan cross sectional yang artinya suatu penelitian untuk mempelajari dinamika korelasi antara faktor-faktor risiko dengan efek dengan cara pendekatan, observasi atau pengumpulan data (Notoatmodjo, 2012).

Populasi dalam penelitian ini adalah seluruh pasien stroke di Rumah Sakit Elisabeth Medan berjumlah 50 orang. Teknik ini menggunakan purposive sampling. Untuk penentuan sampel didapat 
berdasarkan pertimbangan tertentu berjumlah 34 orang.

Rumus dalam mengambil sampel yang digunakan, yaitu:

$$
\mathrm{n} \quad=\frac{\mathrm{N} \mathrm{Z}^{2} \mathrm{P}(1-\mathrm{P})}{\mathrm{N} \mathrm{G}^{2}+\mathrm{Z}^{2} \mathrm{P}(1-\mathrm{P})}
$$

Keterangan:

$$
\begin{aligned}
& \mathrm{n} \quad=\text { Jumlah sampel } \\
& \mathrm{N} \quad=\text { Jumlah populasi } \\
& \mathrm{Z}=\text { Tingkat keandalan 95\% } \\
& (1,96) \\
& \mathrm{P} \quad=\text { Proporsi populasi } \\
& \mathrm{G}=\text { Galat pendugaan }(0,1) \\
& \mathrm{n}= \\
& \mathrm{n}=34 \text { orang }
\end{aligned}
$$

Metode Pengumpulan data dengan menggunakan kuesioner. Analisa data dilakukan dengan menggunakan uji chi square dengan tingkat kemaknaan dengan uji chi square yakni 5\%.
Sebelum penelitian dilakukan, responden yang menjadi sampel diberi penejelasan tentang judul, tujuan penelitian dan menandatangani informed consent (surat persetujuan). Jika ada responden yang menolak berpartisipasi dalam penelitian ini, peneliti tidak memaksa dan tetap menghormati hak-haknya. Kerahasiaan informasi responden dijamin oleh peneliti dan hanya kelompok data tertentu saja yang disajikan dan dilaporkan sebagai hasil riset.

Kuesioner dinyatakan valid dengan nilai $r$ hitung lebih besar dari $r$ tabel $(0,80>$ 0,361) pada taraf signifikansi 5\%. Selanjutnya dilakukan proses pengolahan data dengan langkah-langkah yaitu : editing, koding, entry data dan cleaning. Analisis data menggunakan analisis univariate, analisis bivariat menggunakan Chi

Square.

Tabel 1

Distribusi Frekuensi Karakteristik Pada Pasien Stroke Di Rumah Sakit Santa Elisabeth Medan

\begin{tabular}{lll}
\hline Karakteristik & Frekuensi (f) & Persentase (\%) \\
\hline Umur & & \\
20-40 tahun (Dewasa Muda) & 3 & 7,8 \\
41-60 tahun (Dewasa Tengah) & 17 & 50,0 \\
$>60$ tahun (Lansia) & 14 & 41,2 \\
\hline Jumlah & 34 & 100 \\
\hline JenisKelamin & & \\
Laki-laki & 21 & 61,8 \\
Perempuan & 13 & 38,2 \\
\hline Jumlah & 34 & 100 \\
\hline Agama & & \\
Islam & 4 & 11,8 \\
Kristen & 23 & 67,7 \\
Katolik & 6 & 17,6 \\
Buddha & 1 & 2,9 \\
\hline Jumlah & 34 & 100 \\
\hline
\end{tabular}


Berdasarkan tabel 1 Distribusi frekuensi dan persentase karakteristik pada pasien stroke di Rumah Sakit Santa Elisabeth Medan, diperoleh bahwa sebagian besar yang ikut serta menjadi responden pada usia dewasa tengah sebanyak 17 orang
$(50,0 \%)$, sebagian besar menjadi responden adalah laki-laki sebanyak 21 orang $(61,8 \%)$, sebagian besar agama yang dianut responden adalah kristen sebanyak 23 orang $(67,7 \%)$.

Tabel 2.

Distribusi Frekuensi Responden Berdasarkan Dukungan Keluarga Pada Pasien Stroke Di Rumah Sakit Santa Elisabeth Medan

\begin{tabular}{lll}
\hline Dukungan Keluarga & Frekuensi (f) & Persentase (\%) \\
\hline Baik & 19 & 55,9 \\
Kurang & 15 & 44,1 \\
\hline Jumlah & 34 & 100 \\
\hline
\end{tabular}

Berdasarkan hasil analisis data tabel 2 didapatkan bahwa dari 34 responden di Rumah Sakit Santa Elisabeth Medan yang memiliki memiliki dukungan keluarga yang baik sebanyak 19 orang $(55,9 \%)$ dan dukungan keluarga yang kurang sebanyak 15 orang $(44,1 \%)$.

Dukungan dari keluarga merupakan keadaan yang bermanfaat bagi individu yang diperoleh dari orang lain yang dapat dipercaya, sehingga seseorang akan tahu bahwa ada orang lain yang memperlihatkan, menghargai, dan mencintainya (Setiadi, 2008). Dukungan keluarga mengacu kepada dukungandukungan yang dipandang oleh anggota keluarga sebagai sesuatu yang dapat diadakan untuk keluarga dimana dukungan tersebut bisa atau tidak digunakan, tetapi anggota keluarga memandang bahwa orang yang bersifat mendukung selalu memberikan pertolongan dan bantuan jika dibutuhkan.

Dukungan keluarga yang kurang pada pasien stroke membuat penderita semakin memburuk dalam status kesehatanny, oleh sebab itu, dukungan keluarga sangat berperan penting bagi anggota keluarga yang sakit apalagi pada individu yang mengalami masalah kesehatan seperti kelumpuhan pada anggota gerak sebelah kanan ataupun kiri. Perubahan citra tubuh, membuat konsep dirinya terganggu, sehingga perhatian, motivasi, dan hal-hal lain sebagai pemacu terhadap proses penyembuhan khususnya untuk konsep dirinya membantu dalam pemberian obat dan kebutuhan dasar lainnya.

Berdasarkan hasil penelitian Ambarita (2014) tentang hubungan dukungan keluarga dengan lama rawat pada pasien stroke di Rumah Sakit Santa Elisabeth 
Medan menyatakan bahwa terdapat 60 orang responden yang menunjukkan dukungan keluarga baik 34 orang $(58,7 \%)$, dukungan keluarga cukup 8 orang $(13,3 \%)$ dan dukungan keluarga kurang 18 orang (30\%). Hasil tersebut menunjukkan masih berfungsinya keluarga dalam memberikan dukungan kepada pasien stroke. Hal ini sejalan dengan penelitian Ariyanta (2013) bahwa keluarga sangat berperan dalam memberikan dukungan untuk kesemnuihan pasien. Bentuk-bentuk dukungan keluarga sebatas terhadap kebutuhan sehari-hari pasien, dimana keluarga selalu berusaha untuk memenuhi kebutuhan hidup seharihari pasien misalnya makan, minum, dan tempat berteduh. dapat diperoleh seseorang pasien stroke berupa dukungan informasional yaitu berupa: saran, bantuan yang nyata atau tingkah laku yang diberikan orang yang akrab dengan pasien didalam lingkungan sosial atau berupa kehadiran dan hal yang memberikan keuntungan emosional atau pengaruh kepada tingkah laku penerimanya.

Dukungan keluarga bagi pasien stroke sangatlah dibutuhkan untuk ketentraman hidupnya. Apalagi jika orang tersebut sedang menghadapi masalah kesehatan baik ringan maupun berat. Karena saat itulah seseorang merasa dihargai, diperhatikan, dan dicintai (Kuntjoro, 2002). Hal ini merupakan sikap keluarga dengan melalui interaksi dan reaksi keluarga terhadap anggota keluarga yang sakit dapat meningkatkan kesehatan. Secara psikologis, apabila dukungan dari keluarga penderita stroke mampu mengoptimalkan dukungan emosional, penilaian, informasi, dan instrumental berupa perhatian, nasehat, saran, motivasi maka dukungan keluarga tersebut pada penderita stroke merasa bahwa dirinya dibutuhkan, diperhatikan dan merasa bahwa dirinya tidak berbeda dengan manusia yang lain.

Tabel 3

Distribusi Frekuensi Responden Berdasarkan Konsep Diri Pada Pasien Stroke Di Rumah Sakit Santa Elisabeth Medan

\begin{tabular}{lll}
\hline Konsep Diri & Frekuensi (f) & Persentase (\%) \\
\hline Positif & 11 & 32,4 \\
Negatif & 23 & 67,6 \\
\hline Jumlah & 34 & 100 \\
\hline
\end{tabular}

Konsep diri dapat terjadi pada penderita stroke yang bersifat negatif disebabkan karena memiliki kepribadian buruk dan juga terganggunya citra tubuh pada dirinya sehingga merasa tidak yakin terhadap kondisi kesehatannya serta selalu berpikir merasa dirinya tidak diperhatikan, diterima dan dihargai oleh orang-orang sekitarnya. 
Oleh karena itu, perlu meningkatkan konsep diri yang memiliki kepribadian sehat atau sesuai dan akan terjadi citra tubuh bersifat positif seperti dapat melakukan latihan pergerakan ROM dengan baik, ideal diri yang realistis, harga diri yang tinggi dapat membuat individu berpikir optimis, identitas diri yang dapat mengenali, menerima, dan menguasai dirinya sendiri dan melaksanakan peran dengan baik.

Rohadirja, dkk (2012) tentang konsep diri pada pasien stroke ringan di Poliklinik Saraf RSUD Sumedang menunjukkan bahwa konsep diri pada pasien stroke memiliki konsep diri yang positif $(53,33 \%)$ dan memiliki konsep diri yang negatif (46,67\%). Dalam aspek konsep diri yang negatif pada penelitian ini pasien memandang perubahan dalam dirinya secara negatif, salah satunya pasien merasa tidak disukai orang lain dan tidak dapat menerima keadaannya hal ini akan mempengaruhi konsep diri pasien. Perasaan ini yang membuat pasien merasa stress dan terganggu yang akhirnya dapat memperberat keadaan sakitnya. Penderita dengan penyakit stroke dapat menimbulkan respon salah satunya kehilangan konsep diri atau perubahan konsep dirinya dimana merasa dirinya berubah mencakup bentuk dan fungsi tubuh penderita sehingga tidak dapat berfikir secara rasional terhadap peran dan identitasnya.

Konsep diri setiap individu memandang dirinya secara utuh, seperti fisik, emosi, intelektual, sosial, dan spiritual. Hal-hal yang termasuk dalam konsep diri yang memiliki persepsi individu tentang sifat dan potensi yang dimilikinya, nilai-nilai yang berkaitan dengan pengalaman dan objek, serta tujuan, harapan, dan keinginannya (Sunaryo, 2014). Setiap perubahan dalam masalah kesehatan dapat menjadi stressor yang mempengaruhi konsep diri seperti perubahan fisik dalam tubuh menyebabkan perubahan citra tubuh, dimana identitas, ideal diri, peran dan harga diri juga dapat dipengaruhi pada pasien stroke. Dengan terganggunya konsep diri tersebut adanya respon yang berbeda dari konsep dirinya masingmasing.

Pasien stroke memiliki respon konsep diri berkisar dari status aktualisasi diri (paling adaptif) sampai pada kerancuan identitas/depersonalisasi (maladaptif) yang artinya suatu perasaan yang tidak realistis dan keasingan dirinya dari lingkungan (Azizah, 2011). 
Tabel 4

Hubungan Dukungan Keluarga dengan Konsep Diri Pada Pasien Stroke Di Rumah Sakit Santa Elisabeth Medan

\begin{tabular}{|c|c|c|c|c|c|c|c|}
\hline \multirow{3}{*}{ Dukungan Keluarga } & \multicolumn{6}{|c|}{ Konsep Diri } & \multirow{2}{*}{$P$ value } \\
\hline & \multicolumn{2}{|c|}{ Positif } & \multicolumn{2}{|c|}{ Negatif } & \multicolumn{2}{|c|}{ Total } & \\
\hline & $f$ & $\%$ & $\mathrm{f}$ & $\%$ & $\mathrm{f}$ & $\%$ & \\
\hline Baik & 10 & 52,6 & 9 & 47,4 & 19 & 100 & \multirow{2}{*}{0,004} \\
\hline Kurang & 1 & 6,7 & 14 & 93,3 & 15 & 100 & \\
\hline
\end{tabular}

Berdasarkan hasil analisis tabel 4 diperoleh bahwa hasil analisis hubungan dukungan keluarga dengan konsep diri pada pasien stroke di Rumah Sakit Santa Elisabeth Medan menunjukkan bahwa dari 19 orang, memiliki dukungan keluarga yang baik dengan konsep diri yang positif sebanyak 10 orang $(52,6 \%)$ dan dukungan keluarga yang kurang dengan konsep diri yang negatif sebanyak 9 orang $(47,4 \%)$ sedangkan dari 15 responden, memiliki dukungan keluarga yang kurang dengan konsep diri yang positif ada 1 orang $(6,7 \%)$ sedangkan responden yang memiliki dukungan keluarga yang kurang dengan konsep diri yang negatif sebanyak 14 orang $(93,3 \%)$.

Berdasarkan hasil uji statistik dengan menggunakan uji chi square yaitu $p=0,004<0,05$ berarti ada hubungan yang bermakna antara dukungan keluarga dengan konsep diri pada pasien di Rumah Sakit Santa Elisabeth Medan. Hasil penelitian tersebut sesuai dengan penelitian terdahulu yang dilakukan oleh Ariyanta
(2013) menyimpulkan terdapat hubungan dukungan keluarga dalam pemberian dukungan dengan konsep diri pada penderita kusta di desa Bangklean Doplang Blora. Penelitian lain dilakukan oleh Sartika (2013) tentang "hubungan dukungan keluarga dengan harga diri penderita kusta rawat jalan di Rumah Sakit Rehatta Donorojo Jepara". Penelitian ini menyimpulkan bahwa ada hubungan yang signifikan antara dukungan keluarga dengan harga diri penderita kusta dengan di Rumah Sakit Rehatta Donorojo Jepara. Penelitian ini menunjukkan bahwa semakin baik dukungan keluarga maka harga diri penderita kusta semakin baik.

Hasil penelitian Abidin (2014) menyatakan bahwa ada hubungan keluarga dengan konsep diri pada pasien stroke. Keluarga pasien dapat meningkatkan dan memaksimalkan dukungannya kepada pasien stroke agar tidak terjadi gangguan konsep diri.

Kartini, dkk (2013) menyatakan bahwa dukungan keluarga baik yang konsep 
dirinya positif sebanyak $30 \%$ dan yang konsep dirinya negatif sebanyak 36,7\%. Sedangkan responden yang dukungan keluarganya kurang dengan konsep dirinya positif tidak ada dan yang konsep dirinya negatif sebanyak 33,3\%. Pada penelitian ini didapatkan responden yang dukungan keluarganya baik namun konsep dirinya negatif sebanyak 11 orang. Hal ini menunjukkan bahwa dukungan keluarga bukanlah satu-satunya faktor yang berhubungan dengan konsep diri seseorang. Salah satu faktor yang dapat mempengaruhi konsep diri seseorang adalah faktor sosial budaya dan agama dimana walaupun terjadi perubahan pada diri seseorang termasuk penderita stroke apabila imannya kuat maka dia menganggap apa yang terjadi pada dirinya sebagai suatu cobaan dari Tuhan sehingga tidak ada yang disesalinya dan apa yang menimpanya diterimanya dengan ikhlas.

Dukungan keluarga diperlukan untuk mengubah konsep diri. Pengalaman dalam perawatan di rumah sakit dengan penyakit stroke yang dapat mempengaruhi konsep diri dimana terjadinya perubahan citra tubuh seperti kelumpuhan anggota tubuh, bicara pelo, mulut mencong, dan sebagainya. Bentuk dukungan keluarga yang diberikan pada penderita stroke dalam mengubah setiap konsep diri yang terganggu dapat berupa dukungan instrumental dimana bentuk dukungan ini merupakan penyediaan materi yang dapat memberikan pertolongan langsung seperti penyediaan dana, pemberian barang, makanan serta pelayanan. Bentuk dukungan yang lain dapat diberikan oleh keluarga adalah dukungan informasional dimana keluarga memberikan informasi tentang kondisi kesehatan pasien dan keadaan dirumah, saran tentang apa yang harus dilakukan oleh pasien atau umpan balik tentang situasi dan kondisi pasien yang dapat menolong individu untuk mengenali dan mengatasi masalah dengan mudah. Dukungan emosional pada pasien stroke sangat membantu dalam bentuk perhatian, motivasi, bimbingan dalam proses penyembuhan dan mengubah konsep diri penderita.

Begitu juga dengan konsep diri pada harga diri dapat mengalami penurunan sehingga ada persepsi mengatakan tidak menerima kondisi dirinya akibat terjadinya perubahan fisik tersebut serta peran dan identitas dirinya tidak berjalan sesuai dengan harapan apalagi peran penderita stroke didalam keluarga sebagai ayah ataupun ibu. Setiap konsep diri yang berubah pada penderita stroke diharapkan terjadinya perubahan yang berespon positif sehingga perlunya dukungan keluarga yang dapat mengubah konsep diri tersebut. 


\section{SIMPULAN}

Ada hubungan dukungan keluarga dengan konsep diri pada pasien stroke di Rumah Sakit Santa Elisabeth Medan. Dukungan keluarga yang baik didalamnya terdapat dukungan emosional, informasional, instrumental, dan penilaian akan membantu pasien stroke meningkatkan konsep diri yang baik. Diharapkan perawat meningkatkan pelayanan kepada pasien, memotivasi dan mendampingi anggota keluarga yang sakit serta perawat bekerjasama dengan keluarga dalam mempertahankan konsep diri pasien. Bagi Keluarga agar memperhatikan kondisi kesehatan pasien, memotivasi anggota keluarga yang sakit dengan memberi motivasi untuk sembuh, serta mendampingi pasien dalam proses penyembuhan

\section{DAFTAR RUJUKAN}

Ambarita, N. 2014. Hubungan Dukungan Keluarga Dengan Lama Rawat Di Rumah Sakit Santa Elisabeth Medan. Medan: Program Studi Ners STIKes Santa Elisabeth Medan

Anderson, 2008 gejala stroke dan cara pencegahannya. Diakses 15 Oktober 2015. www.vibizlife.com

Ariyanata F 2013, Hubungan Antara Dukungan Keluarga Dengan Konsep Diri Penderita Kusta Di Desa Bangklean Kabupaten Blora. Fakultas
Ilmu Kesehatan Universitas Muhammadiyah Surakarta.

Azizah, L. 2011. Keperawatan Jiwa Aplikasi Praktik Klinik. Yogjakarta: Graha Ilmu

Fazilla A 2015. Hubungan Dukungan Keluarga Dengan Konsepdiri Pada Pasien Stroke Di Rehabilitasi Medik Rssn Bukittinggi Tahun 2014. Diploma Thesis, Universitas Andalas.

Harmoko. 2012. Asuhan Keperawatan Keluarga. Semarang: Pustaka Pelajar

Hasan. 2013. Hubungan Antara Dukungan Sosial Dengan Strategi Coping Pada Penderita Stroke RSUD Dr. Moewardi Surakarta. Jurnal Keperawatan Medikal Bedah, Vol. 2, No. 1. Diakses $12 \quad$ Oktober 2015 http://jurnal.usahidsolo.ac.id/index.ph p/talenta/article/.../0

Hidayat, A. 2009. Metode Penelitian Keperawatan dan Teknik Analisa Data. Jakarta: Salemba Medika

Kartini, dkk. 2013. Hubungan Dukungan Keluarga Dengan Perubahan Konsep Diri Pada Pasien Pasca Stroke Di Poliklinik Saraf Rumah Sakit Khusus Daerah Provinsi Sulawesi Selatan. Jurnal Keperawatan Medikal Bedah, Vol. 3, No. 1. Diakses 19 November 2015. http:library.stikesnh.ac.id/.../elibrary $\% 20$ stikes $\% 20$ nani $\% 2$

Keliat, B. 2011. Manajemen Kasus Gangguan Jiwa CMHN (Intermediate Course). Jakarta: EGC 
Kluwer, W. 2012. Kapita Selekta Penyakit dengan Implikasi Keperawatan. Edisi 2. Jakarta: EGC

Kuntjoro, Z. 2002. Dukungan Sosial Pada Lansia. Diakses 12 Oktober 2015 http://www.epsikologi.com/.../dukung an-sosial-pada-lansia

Mandal, A. 2014. Stroke Epidemiology. Diakses 12 Oktober 2015) http://www.newsmedical.net/health/StrokeEpidemiology.aspx,

Muttaqin, A. 2008. Asuhan Keperawatan Klien dengan Gangguan Sistem Persarafan. Jakarta: Salemba Medika

Notoatmodjo, S. 2012. Metodologi Penelitian Kesehatan.. Jakarta: Rineka Cipta

Nursalam.. 2013. Metodologi Penelitian Ilmu Keperawatan Pendekatan Praktis, Edisi 3. Jakarta: Salemba Medika

Prince \& Wilson. 2006. Patofisiologi Konsep Klinis Proses-Proses Penyakit, Edisi 6, Volume 2. Jakarta: EGC

Potter, P \& Perry, A. 2009. Fundamental Keperawatan, Buku 1, Edisi 7. Jakarta: Salemba Medika

Pudiastuti, R. 2011. Penyakit Pemicu Stroke. Yogjakarta: Nuha Medika

Purwaningsih, W. 2010. Asuhan Keperawatan Jiwa. Yogjakarta: Nuha Medika

Riskesdas, 2013. Riset Kesehatan Dasar. Badan Penelitian dan Pengembangan Kesehatan Kementerian Kesehatan RI. Jakarta.
Rohadirja, R. 2012. Konsep Diri Pada Pasien Stroke Ringan Di Poliklinik Saraf RSUD Sumedang. Jurnal Keperawatan Medikal Bedah, Vol. 1 No. 1 diakses 12 Oktober 2015) http://journals.unpad.ac.id

Saam, Z \&Wahyuni, S. (2013). Psikologi Keperawatan. Jakarta: Rajawali Pers

Sartika, D. L. 2013. Hubungan Dukungan Keluarga dengan Harga Diri Penderita Kusta Rawat Jalan di Rumah Sakit Rehatta Donorojo Jepara. $\quad$ Semarang: $\quad$ STIKES Telogorejo.

Septinopalinda \& Agustin. 2013. Hubungan Keluarga Dengan Konsep Diri Pasien Kanker Payudara Di RSUP Dr. Moh. Hoesin Palembang. Palembang: Program Studi Ilmu Keperawatan STIK Bina Husada Palembang

Setiadi. 2008. Konsep dan Proses Keperawatan Keluarga, Edisi 1. Yogyakarta: Graha Ilmu

Sudiharto. 2007. Asuhan Keperawatan Keluarga dengan Pendekatan Keperawatan Transkultural. Jakarta: EGC

Sugiyono. 2013. Metode Penelitian Kuantitatif Kualitatif dan $R$ \& D. Bandung: Alfabeta

Sunaryo. 2014. Psikologi Untuk Keperawatan, Edisi 2. Jakarta: EGC

Susanto, T. 2012. Buku Ajar Keperawatan Keluarga: Aplikasi Teori Pada Praktik Asuhan Keperawatan Keluarga. Jakarta: Trans Info Media. 